\title{
Sociobiology, Racism and Australian Colonisation
}

Allan Ardill ${ }^{*}$

\begin{abstract}
Sociobiology is a relatively modern science but it is based on the very old premise that human beings are products of immutable laws of nature. For this reason it can be shown that sociobiology is an idea that envelopes a family of biblical and scientific theories that have been shown to be ideologies for the justification of hierarchy and oppression over the course of recorded human history. This family of sociobiological theories depicts 'race', and hierarchy based on race, as natural and inevitable. Here the argument is made that sociobiology is an ideology for the colonisation of Australia. Sociobiology is an ideology implicit in Australian legal doctrine and active in a continuing colonial process as a 'justification' for the annexation of Australia in the late eighteenth century as well as the domination that took place after 1788 through dispossession, denial of sovereignty, and policies of assimilation and exploitation.
\end{abstract}

\section{Introduction}

In this essay, it is argued that sociobiology was and remains an ideology for the colonisation of Australia. The arguments made here are not novel, and can be found in historical and sociological work outside legal literature.' They are, however, relatively novel within legal scholarship, where very little is written connecting law and scientific racism in the Australian context. ${ }^{2}$ In this essay, it is argued that

\section{Lecturer, Griffith Law School.}

For example, Balibar and Wallerstein (1991); Barta (2001); Evans (1999); Hofstadter (1959); Jones (1980).

There are important exceptions. The first is an excellent brief coverage of some links between 'sociobiology', colonialism, liberalism and racism provided by Clarke (1997). Another important exception is the excellent essay by De Plevitz and Croft (2003) on 'Aboriginal identity'. However, the argument in both pieces is necessarily narrower than the more general one made in this essay. In an American context, there is the separate work of Fitzpatrick (2001), Lombardo (1996) and Sealing (2000). Although Fitzpatrick links science with racism in the context of colonisation, his work is not concerned with the family of theories I have classified here as sociobiology, and which I have treated as a dominant legal ideology. For example, Fitzpatrick makes some connections between sociobiology and imperialism, but doesn't continue the argument through until the present by dealing with assimilation and recent trends in Indigenous identity and native title cases. Lombardo shows that, in the first part of the twentieth century, eugenics was axiomatic and ubiquitous in American culture, and was an official policy implemented by law. And Sealing presents an argument remarkably similar to mine - albeit better argued and confined to a critique of the roles played by biology and theology as forms of scientific racism underpinning the United States anti'miscegenation' laws banning 'inter-racial' sex and marriage in the United States. 
sociobiology envelopes what others describe as scientific racism. In particular, I argue that sociobiology is an ideology implicit in Australian legal doctrine and active in a continuing colonial process.

However, to make this argument, it is necessary to begin this essay with some elaboration of the term 'sociobiology'. This is because, at first glance, it seems incongruous that sociobiology could be considered an ideology for the colonisation of Australia, since the term was coined by Wilson in 1975 and the 'First Fleet' arrived in 1788. For my argument to stand, it must be shown that sociobiology was a 'justification' for the annexation of Australia in the late eighteenth century as well as for the domination taking place after 1788 ( viz dispossession, denial of sovereignty and policies of assimilation). It must be shown that sociobiology has retained a continuous discernable character from the eighteenth century through until the twenty-first century, and that it had a bearing on people's lives. ${ }^{3}$

Therefore, this essay commences with an elaboration of the term 'sociobiology' before exploring its significance for the colonisation, dispossession and 'protection' of Indigenous Australians. It is argued that a family of theories I describe as 'sociobiology' has been, and continues to be, a justification for the colonisation of Australia, in order to deny Indigenous sovereignty, to dispossess Indigenous people and to pursue policies of assimilation, exploitation and domination of Indigenous people.

\section{Racism and Sociobiology}

\section{A History of Naturalising Theories}

For present purposes, sociobiology can be understood as having at least three overlapping meanings. Sociobiology is a formal science; it is also a matrix of assumptions about human nature; and it is an ideology. ${ }^{4}$ The common thread linking each meaning is that there is some innate basis to human nature. Better known elsewhere as 'biological determinism', it can be thought of as the idea that differences between humans can be reduced to biological explanations, or that difference is biologically determined. 5 Thought of in this way, the science of sociobiology is a revision of several earlier traditions in 'scholarly' thought. In other words, in broad terms, sociobiology can be properly thought of as a family of 'scholarly' theories, starting with the theological notions of monogenesis and

Dain (2004) and Miller (2004) have made similar arguments to this with different concerns and emphasis. Sealing (2000), p 265 too makes a similar argument, commenting: 'Whether rooted in science or theology, and regardless of the changes wrought by time, change in circumstance, and new scientific revelations, a consistent paradigm that justified miscegenation in many American states from colonial times to 1967 emerged.'

4 Sociobiology was introduced to the world as a formal science by Edward O Wilson (1976). Sociobiology can also be a matrix of ideas about the place of humans in nature and the nature of humans, as articulated in Young (1985). Further, sociobiology has been depicted as an ideology by many. In particular, see Haraway (1991); Munoz-Rubio (2003); Tinker (1988).

Miller and Costello (2001). 
polygenesis, then later phrenology in the pre-Darwin era, through to eugenics, sociobiology and evolutionary psychology in the post-Darwin era. ${ }^{6}$

Each theory is linked by the idea that there is some innate basis to human nature, whether made by God (monogenesis) or made by genes (sociobiology), for example. Each theory is also linked by the privileged standpoint of the scholars who projected their view of society on to nature, and then in turn used that 'nature' to account for the physical structure and culture of society and individuals. Stated another way, each of these theories was used to replicate existing power structures by 'justifying' human action as natural and inevitable. For these reasons, sociobiology can be said to have been a dominant racist ideology over the last 300 years despite the term's etymological origins in biology, which only became popular after Darwin penned On the Origin of Species in 1859.

Theories based on assumptions about (1) the place of man in nature, and (2) the nature of man predated Darwin. ${ }^{7}$ This is not a controversial point, and is widely recognised by historians of the philosophy of science and those who have written specifically on the history of the theory of evolution or the history of social Darwinism. ${ }^{8}$ Indeed, Darwin himself recognised as much, crediting Malthus ${ }^{9}$ as providing him with the 'mechanism' ('struggle for existence') for his theory of evolution according to natural selection. ${ }^{10}$ Malthus postulated the idea that populations grow faster than their food supply, and therefore there is a need to restrain population growth and exercise economy with respect to food. For this reason, it is better to regard Darwin's famous essay of 1859, and the contemporary essays of Spencer ${ }^{11}$ and Wallace ${ }^{12}$ (widely regarded as co-founders of the theory of evolution), as consolidations and syntheses of the literature that preceded them. ${ }^{13}$

Prior to the development of the theory of evolution in the mid-nineteenth century, there were three other important sociobiological theories (viz, ones about

6 This essay does not consider the role of 'evolutionary psychology' in any depth, or attribute it to Australian colonisation. However, I have argued elsewhere (in Ardill, 2008, p 19) that evolutionary psychology is an ideology within this tradition of naturalising theories, and it is regarded by its proponents as the successor or next version of sociobiology (see, for example, the Society for the Evolutionary Analysis of Law website at www.sealsite.org; Dunbar (2005); Badcock (2000); Edwards (2003); cf Selin (1999), who rejects the idea that evolutionary psychology is the new human sociobiology).

In fact, Aristotle (384-322 BC) wrote specifically on these issues: see Saunders (1992), Chapter 2.

$8 \quad$ In particular, Gould (1991); Hofstadter (1959); Jones (1980); Richards (1987); Ruse (2005); Young (1985).

Malthus (1960 [1830]), p 35.

10 Darwin (1859), pp 13 and 53. Gould (1991), pp 21-22 points out that Darwin also credited Malthus in his autobiography, written several years after On the Origin of Species, 'until Malthus's vision of struggle and crowding catalyzed his thoughts, he [Darwin] had not been able to identify an agent for natural selection'.

11 Spencer (1857).

12 Wallace (1864).

13 Gould (1991); Hofstadter (1959); Jones (1980); Richards (1987); Ruse (2005). 
the place of man in nature and the nature of man), among others, ${ }^{14}$ namely 'monogenism', 'polygenism' and 'phrenology'. After Darwin's theory of evolution came 'social-Darwinism', 'eugenics' and ultimately the formal discipline of sociobiology.

Linking this chain of theories (monogenism, polygenism, phrenology, Darwin's theory of evolution, social Darwinism, eugenics and sociobiology), among other things, is their racist essence. ${ }^{15}$ That is to say, they are all concerned with the place of race in nature and the nature of races, and to this extent they have played an ideological role in hierarchy, colonisation and slavery. ${ }^{16}$ While the core principle of racial hierarchy remained relatively static, being recycled in each of the theories over time, the form each theory took changed over time, reflecting shifting paradigms in science, culture, and structural changes to economic systems and technology ${ }^{17}$ Still, it would be a misrepresentation to claim that these theories were merely a reaction to changing material circumstances because they have also functioned to justify material change; therefore the relationship is dialectical. ${ }^{18}$

\section{Monogenesis and Polygenesis}

Two of the earlier forms of racist theories belonging to the family of theories I call sociobiology were 'monogenesis' and 'polygenesis'. These two theories purported to account for the differences between human races based on whether or not there

${ }_{14}$ For example, it can be demonstrated that the social contract theories of Locke and Hobbes were essentially theories about the place of man in nature and the nature of man, since both men presumed virtually opposite starting points for their justifications for the social contract given their views of human nature. For Hobbes, the natural state of man was nasty, selfish and brutish, while Locke criticised Hobbes for his dim view of human nature. This argument is developed below.

15 These theories are also linked by their bio-fatalist and discriminatory stances on gender, sexuality, class and disability.

16 Gould (1991), p 258: 'As I argue in the preceding set of essays, biological determinism has always been used to defend existing social arrangements as biologically inevitable - from 'for ye have the poor always with you' to nineteenth-century imperialism to modern sexism ... But I reiterate my statement that no evidence exists to support it, that the crude versions of past centuries have been conclusively disproved, and that its continued popularity is a function of social prejudice among those who benefit most from the status quo.'

17 For example, the Christian concept of 'monogenism' was challenged by 'polygenism' due to the impact of Darwin's theory of evolution on a literal interpretation of the Bible, and passages referring to Adam and Eve, and Noah saving species from the great flood. See further below.

18 Firestone (1972), p 12; Seshadri-Crooks (2000), p 14, citing Goldberg (1993), p 81; Young (1985), pp 166-67; Jones (1980), p 147: 'Biology helped create the kind of moral universe in which nature reflected society and vice versa. The idea of a parallel between the two had been popular before Darwin. It was expressed most succinctly in Paley's natural theology. The immediate impact of Darwin was, in fact, to shatter the universe by undermining the notion of stability and lack of change in nature.' But long before Paley wrote his version of the metaphor, Aristotle had penned his, per Saunders (1992). 
was one single origin for the human race or multiple origins. ${ }^{19}$ Both theories were based on the Bible. ${ }^{20}$ However, monogenesis was dominant because it had broader support within Christian literalist circles. ${ }^{21}$ Monogenesis held that human beings had all descended either from the common ancestors Adam and Eve or, after the flood, directly from Noah's three sons and their wives. ${ }^{22}$ The more heretical polygenesis contended that God had created different races, or that different races had subsequently emerged as a result of attracting God's wrath, and later still, as a result of evolutionary pressures. ${ }^{23}$ This latter polygenist theory gained broader acceptance after the publication of Darwin's thesis in 1859. Evolutionary theory undermined literal Biblical accounts of human history because monogenesis could not explain the great variation in human morphology, given there had been very few generations between the time of Adam and Eve - or indeed Noah — and the midnineteenth century. ${ }^{24}$

Racism was 'justified' by monogenesis on the basis that, although God had produced all humans through Adam and Eve, since then some races had been disfavoured by God because of their uncivilised non-Christian conduct. ${ }^{25}$ Alternatively, they were deemed 'Pre-Adamite', and therefore sub-human. Racism was 'justified' by polygenesis on grounds that God had created different races for different climates with the result that some were better endowed than others. ${ }^{26}$ In

19 Bernasconi (2002); Evans (1999); Sealing (2000).

${ }^{20}$ Although polygenism was a biblical theory, it was considered heretical until the middle of the nineteenth century, when it gained prominence (mostly in the United States) as a counter-response to literal interpretations of the Bible. Advocates of a literal interpretation of the Bible struggled to reconcile archaeological, anthropological and geological evidence, which tended to suggest a considerably longer timeframe for the rich diversity in human traits than would be possible in the few generations since Noah and the flood. The biblical account required extremely quick evolution. See further Sealing (2000), p 573; Bernasconi (2002), p 1: 'When in the seventeenth century Northern Europeans began to receive detailed information about Africans and Native Americans, they recognized that the physical differences among the human varieties raised problems for their commitment to the chronology set out in the Bible.'

${ }_{21}$ Monogenism held that all humans had descended from Noah's three sons and their wives (Shem, Ham and Japeth), and that the 'races' (white, yellow, red, brown and black) had developed from the varying degrees of the degeneration of Noah's children and their descendants, per Sealing (2000), pp 571-76.

Sealing (2000), pp 571-74.

Sealing (2000), pp 576, 578-82.

Sealing (2000), p 573.

$25 \quad$ Bernasconi (2002), p 1; Sealing (2000), p 576.

26 Bernasconi (2002), pp 1-2: 'Kames was not concerned with questions of Biblical scholarship so much as with certain scientific problems. However, sensitivity to religious controversy led him to propose polygenesis only tentatively in the form of a question. Because he doubted that climate alone could have brought about all the differences between the human varieties, he raised the question of whether the different varieties had not been made for different climates, a position supported in his view by the difficulties that Europeans had in adapting to warm climates. Kames believed that 
either case, these theories about the place of humans in nature and the nature of humans provided 'justification' for European (and later American) invasions and colonisation, and underpinned slavery for centuries. ${ }^{27}$ Significantly, Barta points to the role of polygenesis in the colonisation of Australia, where a presumption was that 'the great white race' was entitled to take territory inhabited by 'lesser breeds'. ${ }^{28}$

\section{Phrenology}

In the early part of the nineteenth century, 'phrenology' was a 'widespread cultural phenomenon' as well as accepted science. ${ }^{29}$ Phrenology was a theory linking human nature to human morphology, in particular through brain anatomy and skull size. Its first advocate was Franz Gall, who developed his system of 'organology' and brain anatomy in Vienna in the 1790s. ${ }^{30}$ However, it was Edinburgh lawyer George Combe who was to become its most ardent promoter, and his work was widely received in both England and America. ${ }^{31}$ George Combe's promotion of phrenology coincided with his views on the centrality of natural law. Combe's 1828 The Constitution of Man was:

about how natural laws are the ultimate authorities which man must obey, and their action leads to progress; disobeying them leads to automatic punishment. $^{32}$

The significance of Combe's influence on social theory, politics and society should not be under-estimated, given that The Constitution of Man sold seven times

the Native Americans were not pre-Adamite but post-Adamite, thereby adding to the variant forms of polygenesis.' See also Sealing (2000), p 578.

As Hofstadter (1959), p 180 explains, during the US Senate debates about whether to colonise the Philippines, Senator Beveridge decreed: 'God has not been preparing the English-speaking and Teutonic peoples for a thousand years for nothing but vain and idle self-admiration. No! He has made us master organizers of the world to establish system where chaos reigns ... he has made us adepts in government that we may administer government among savages and senile peoples.' This same rationale was used by the United States and its coalition partners to invade Iraq in 2003, in addition to the infamous 'weapons of mass destruction' assertion. See further 'Tony Jones Speaks With Columnist Frank Rich', Lateline, ABC, broadcast 26 February 2007. In terms of slavery, for example: 'John Bachman, the most outspoken defender of monogenism among natural historians in mid-century, was both a slaveholder and a defender of slavery. Nevertheless, the most prominent abolitionists were also monogenists.' Per Bernasconi (2002), p 5.

Barta (2001), p 45. van Wyhe (nd) 'Reading Phrenology'.

van Wyhe (nd) 'Overview of the Chronology of Phrenology'; Jones (1980), pp 104-05. van Wyhe (nd) 'Reading Phrenology'; and 'Overview of the Chronology of Phrenology'. van Wyhe (nd) 'Reading Phrenology'. 
as many copies as Darwin's On the Origin of Species. ${ }^{33}$ It underpinned anthropology for centuries. ${ }^{34}$ Phrenology was apparent in the work of Paul Broca in the United States in the latter half of the nineteenth century. Broca was infamous for his science 'of determining intelligence based on brain size' and fudging measurements so that blacks were deemed inferior to whites. ${ }^{35}$

Once again, a theory of the nature of humans and the place of humans in nature was used to justify racism. ${ }^{36}$ The racism informing phrenology spilled over into all the other disciplines that drew upon it, including Darwin's theory of evolution. ${ }^{37}$ For instance, in America, as a counter to the emerging abolitionist theology (monogenesis) drawing on scripture to counter slavery, a few pro-slavery writers began to draw on science to neutralise the counter-argument. Drawing on science:

To prove the African race's innate and unchanging inferiority, Samuel George, Josiah C. Nott and George R. Gliddon, members of the American or Morton School of ethnology, availed themselves of the latest scientific theories of race and what Morton described as 'the most ancient human remains at present known to us', human skulls excavated from the ancient Egyptian tombs. ${ }^{38}$

This suggests the closeness of thought among the family of ideas I refer to as sociobiology because phrenology was used here to buttress conflicts between and within monogenesis and polygenesis, as those arguments were used on both sides of the abolitionist and anti-abolitionist 'debates' on slavery. ${ }^{39}$

33 van Wyhe (1847). Combe's book sold 350,000 copies between 1828 and 1900, while Darwin's book sold 50,000 copies from 1859 to 1900 . However, Combe's book was a thesis on natural philosophy, situating man's place in nature, rather than a treatise on phrenology.

$34 \quad$ Grene and Depew (2004), pp 321-22.

$35 \quad$ Sealing (2000), p 581.

$36 \quad$ Wohl (nd): 'The science of phrenology, whose heyday was between 1820 and 1850, and later racial anthropological physiognomy, attracted many followers. That man's physical and, by extension, moral, intellectual, and social development, could be determined by, and seen in, his physiognomy - in, say, jaw structure and shape of the head - were to many respected sciences that enjoyed wide currency ... After Darwin popularized the idea that humans are descended from apes, the prognathous (protruding) jaw became a sign of lower development and of a closer relationship to primitive man. It also became the basis of much racial stereotyping of the Irish, and racial anthropologists argued that working class people were more prognathous than their social superiors- who were selfflatteringly described as also biologically superior ... These late nineteenth-century anatomical and anthropological descriptions of "races" and their characteristics, measurements etc. were later the inspiration for the sort of mid twentieth-century racial anthropology as promulgated in Nazi Germany.' Young (1985), p 64; Miller (2004), p 4.

$38 \quad$ Miller (2004), p 2, quoting Morton (1844), p 94.

39 See further Bernasconi (2002); Dain (2004); Miller (2004). 
This family of sociobiological ideas became more potent with the publication of Darwin's essay in 1859, leading to 'social Darwinism' and, later still, 'eugenics'. ${ }^{40}$

\section{Social Darwinism}

'Social Darwinism' can be described as a body of literature drawing on the work of Herbert Spencer, among others, and was the process of analogising and borrowing from Darwin's theory of evolution to apply these ideas beyond biology. ${ }^{41}$ As Hofstadter pointed out:

Herbert Spencer, who of all men made the most ambitious attempt to systematize the implications of evolution in fields other than biology itself, was far more popular in the United States then he was in his native country.

England gave Darwin to the world, but the United States gave Darwinism an unusually quick and sympathetic reception..$^{42}$

Social Darwinism was enthusiastically received in the United States because it correlated with the conservative agenda of those seeking to prevent reform:

It was those who wished to defend the political status quo, above all the laissez-faire conservatives, who were first to pick up the instruments of social argument that were forged out of the Darwinian concepts. ${ }^{43}$

Those 'Darwinian concepts' were the notions of 'struggle for existence', 'survival of the fittest' and 'progress'. As metaphors for politics, conservatives could argue that society could only progress under circumstances where there was no artificial interference (in other words, taxes or the provision of welfare) in the competition for survival, because only the fittest would survive and therefore the society would improve. To interfere with this process was to work against nature, and therefore state intervention into the economy should be kept to the bare minimum. But these same arguments also fuelled the reformers, who could argue that intervention might be desirable to facilitate natural progression. For example, they were invoked to justify colonialism on the basis that 'superior people and their ways' might be used to benefit others. ${ }^{44}$

40 Of course, Darwin's own work was not free of racism, and was rich with the influence of Galton's eugenics. See further Darwin (1871), pp 154-55, 159-60, 167-70, 172-74, 179. It should be added, though, that this tendency is counterbalanced elsewhere by passages renouncing the idea of racial superiority based on evolution - see, for example, pp 182-84.

${ }^{41}$ Spencer was one of the three founders of the theory of evolution, along with Darwin and Wallace. Spencer had overlooked natural selection as a mechanism for evolution until he was alerted to it by the work of Darwin and Wallace. See further Young (1985), pp $48-50$.

$42 \quad$ Hofstadter (1959), p 5.

$43 \quad$ Hofstadter (1959), pp 5-6.

$44 \quad$ Jones (1980), p 151. 


\section{Eugenics}

'Eugenics' developed alongside social Darwinism, but didn't come to prominence until the early part of the twentieth century. Eugenics was founded in the 1860s by Francis Galton, with the 'aim of raising the physical and mental level of the race'. ${ }^{45}$ This was to be achieved by applying Darwin and Spencer's ideas to public policy so that the 'better stocks' were encouraged to reproduce and the weaker stocks were discouraged or prevented from breeding. ${ }^{46}$ These ideas were slow to take off, but quickly spread around the world in the early part on the twentieth century after acceptance of Weismann's germ-plasm theory and the belated recognition of Mendel's hereditary genetics in England. ${ }^{47}$ The 'eugenics movement' drew upon the authority of Darwin, Spencer, Mendel, Malthus and Haeckel to argue the case for the selective breeding of humans. ${ }^{48}$

Unlike its earlier social Darwinist counterpart, the eugenics movement was not as concerned with laissez-faire politics as it was with preserving and improving the racial stock of the nation, and avoiding its dilution through mixing with 'morons' and the 'racially inferior'. ${ }^{9}$ In other words, eugenics stood for the practical application of hereditary principles to state-sanctioned controls to breed out the 'unfit'. In the United States, it received 'practical application in 1907, when Indiana became the first state to adopt a sterilization law; by 1915 twelve states had passed similar measures'. ${ }^{50}$ Notably, in 1927 in Buck $v$ Bell these laws were upheld in the US Supreme Court, with Holmes J declaring: 'Three generations of imbeciles are enough.' ${ }^{51}$ Taken to greater extremes, eugenics provided the Nazis with an excuse

$45 \quad$ Jones (1980), p 99 points out that: 'This idea was based on two propositions: first, that desirable physical and mental qualities were unevenly distributed throughout the population and, second, that those who had the desirable qualities could be identified and encouraged to multiply faster than the others. This, he argued, could be accomplished partly by various forms of state intervention and partly by placing a high social value on the fertility of the better stocks in society.'

46 Jones (1980), p 99.

$47 \quad$ Hofstadter (1959), pp 161, 163.

48 Hofstadter (1959), p 193: 'Common among men of learning was the conception, taken over from Haeckel's Biogentic Law, that since the development of the individual is a recapitulation of the development of race, primitives must be considered as being in the arrested stages of childhood or adolescence — "half devil and half child", as Rudyard Kipling had said.' This certainly resonates with narrative of Blackstone in his Commentaries as quoted by Brennan J at 34-35 in Mabov Queensland (1992) 175 CLR 1: Blackstone's Commentaries Book 1, Chapter 4, pp 106-08. Hofstadter (1959), p 162, citing H.H. Laughlin 'for a review of the progress of eugenics legislation'.

51

Buck v Bell 274 US 200 (1927). Holmes J, in delivering the opinion of the court, held that Carrie Buck, 'a feeble-minded white woman ... and mother of an illegitimate feeble-minded child', could be sterilised according to Virginian law. The judge justified this decision in part: "We have seen more than once that the public welfare may call upon the best citizens for their lives. It would be strange if it could not call upon those who already sap the strength of the State for these lesser sacrifices, often not felt to be such by those concerned, in order to prevent our being swamped with incompetence. It 
for the genocide of Jews and the mass murder of Gypsies, the disabled and homosexuals, along with other disfavoured groups such as trade unionists. ${ }^{52}$ In Australia, eugenics helped shift government policies facilitating the dispossession of Indigenous people to acts of segregation and then assimilation..$^{53}$ The influence of eugenics remains in Australia to this day as a legacy of the stolen generations..$^{54}$ In other words, eugenics was applied as a policy, implemented by state laws, to forcibly remove Indigenous children from their families, either on the basis that they would be assimilated into white society or that they would breed with whites so that ultimately 'pure' Indigenous people would die out. ${ }^{5 s}$

is better for all the world, if instead of waiting to execute degenerate offspring for crime, or to let them starve for their imbecility, society can prevent those who are manifestly unfit from continuing their kind. The principle that sustains compulsory vaccination is broad enough to cover cutting the Fallopian tubes.'

$52 \quad$ Barta (2001), p 46.

53 Evans (1999), pp 117-25. In particular, Evans discusses the 1897 An Act to Make Provision for the Better Protection and Care of the Aboriginal and Half-Caste Inhabitants of the Colony and to Make More Effectual Provision for Restricting the Sale and Distribution of Opium at 124. And at 117: 'fear of racial degeneration, impelled by eugenic calculations about mental and physical fitness, gripped Western societies at the close of the nineteenth century. The expulsion of "degenerate sub-types", defined by those societies to include the insane, the criminal, the prostitute, the homosexual as well as, in white settler regions like Australia, the surviving remnants of so-called "savage races", became a foremost priority ... Thus, racial removal policy developed as a branch of deviancy control and was extended beyond Aboriginal target groups by various pieces of colonial and Commonwealth legislation framing the "White Australia Policy" to include/exclude Pacific Islanders, Asians and Africans ... This in the case of Aboriginal segregation, any sense of reformist concern or philanthropy ... was far less evident than an expanding social alarm about the moral, medical and racial threats these beings posed to a society now striving fitfully towards bourgeois respectability and nationhood.'

${ }_{54}$ The report of the inquiry, Bringing Them Home, was tabled in the Commonwealth Parliament on 26 May 1997. The report found that, in the years 1910-70, up to onethird of all Indigenous children were forcibly removed from their parents under Australian state laws. Among several of the recommendations of the report is Recommendation 5A, which called for recognition of this oppression by way of a formal apology. That apology finally (and belatedly) came in early 2008, following the election of the Rudd Labor government in 2007. See also Flynn and Stanton (2000).

Bringing Them Home: National Inquiry into the Separation of Aboriginal and Torres Strait Islander Children from Their Families 1997, p 94: 'By the 1930s Neville had refined his ideas of integrating Indigenous people into non-Indigenous society. His model was a biological one of "absorption" or "assimilation", argued in the language of genetics. Unlike the ideology of racial purity that emerged in Germany from eugenics, according to which "impure races" had to be prevented from "contaminating" the pure Aryan race, Neville argued the advantages of "miscegenation" between Aboriginal and white people. The key issue to Neville was skin colour. Once "half-castes" were sufficiently white in colour they would become like white people. After two or three generations the process of acceptance in the non-Indigenous community would be complete, the older generations would have died and the settlements could be closed.' 


\section{Sociobiology: The discipline}

Sociobiology is an academic discipline. It emerged in the work of a handful of scholars during the twentieth century and took the formal name 'sociobiology' from the book Sociobiology: The New Synthesis, written by Edward O. Wilson in 1975. ${ }^{56}$ Sociobiology is a more sophisticated reworked version of its predecessors, monogenesis (and polygenesis), phrenology, social Darwinism, and eugenics. ${ }^{57}$ Indeed, a founding sociobiologist, Alexander, suggested a link between 'aggression' and the capacity for assimilation to take place under colonial rule. ${ }^{58}$ Since its inception as a formal discipline, sociobiology has enjoyed a mixed scholarly reception, ${ }^{59}$ and as such persists more as an influence within new fields of social theory, or as a subtle influence on others, than it does as a discipline in its own right. ${ }^{60}$

Therefore, in the material below, 'sociobiology' is taken to include any assertion or theory about the place of humans in nature or human nature, used to

56 Wilson (1976). Among the pioneers of sociobiology was Ernst Mayr (1942, while Badcock mentions the work of 'W.D. Hamilton, R. Trivers, D. Lack, and others' in Badcock (1991), pp xi-xiii.

57 Holden (1996).

58 Alexander (1975), p 94: 'Nor is genetic difference necessarily relevant to the overwhelming of one group by another, at least not in the manner usually considered. All that is implied is that "men who were arranged in groups or teams, each dominated by a spirit of unity, would conquer or outlive men who were not thus grouped" [Keith (1949), p 43]. We have observed, within recorded human history, the aggressive expansion of Western Europeans into the New World and Australia, in particular, and their replacement through decades of the populations that previously inhabited the continents involved. The genetic change that has occurred is not necessarily relevant to the success of the invaders; more relevant is the cultural background that provided the migrating Europeans with vastly superior weapons, agriculture, and technology. Also relevant are those cultural and genetic differences between the invaders and the invaded which reduced the likelihood of amalgamation. Aboriginals who resemble invaders physically are more likely to be assimilated genetically, just as those whose culture is such as to make them pliable in the face of alien domination are more likely to survive alongside and with the invaders.'

59 In 1996 the Human Behaviour and Evolution Society changed the name of its journal from Ethology and Sociobiology to Evolution and Human Behaviour in an attempt to shed the baggage of controversy. The critics were many, among them Gould (1991) and Montagu (1980).

${ }^{60}$ So much so that it now has branches into psychology (evolutionary psychology) and economics (new institutional economics), for example: Eisler and Levine (2002); Watkins (1998). But its impact extends to many other contemporary disciplines, where it is firmly entrenched in schools of anthropology, archaeology, biology, law and economics, and sociology among many others (see, for example, Edwards (2003); Freese and Powell (2001); Hirshman (1998), p 189; Hochman (1992); Holton (1998); Munoz-Rubio (2002); Sigmund and Nowak (2000); Wells (1993); and generally the 'Proceedings of the Pittsburgh Workshop in History and Philosophy of Biology', Centre for the Philosophy of Science, University of Pittsburgh, 23-24 March 2001, http://philsci-archive.pitt.edu. Tinker (1988) explains the connections between sociobiology and commercial disciplines. 
justify racial hierarchy or domination of a social, political or economic kind. The remainder of this essay provides evidence that sociobiological theories (monogenism, polygenism, phrenology, social-Darwinism, eugenics and sociobiology) were fundamental to Australian colonisation (which involved the usurpation of sovereignty, the dispossession of Indigenous people, policies of assimilation, and the maintenance of domination and exploitation of Indigenous Australians). These policies were implemented by law, and to this extent the law is sociobiological.

\section{Colonisation}

\section{Sovereignty}

Australia was a territory taken according to the legal doctrine of discovery. ${ }^{61}$ This was one of the three recognised ways a colonial power could colonise territory according to international law: conquest, cession and discovery of uninhabited land (viz terra nullius). ${ }^{62}$ Because different legal consequences flowed from each of these international law doctrines - the former two doctrines afforded more legal recognition for Indigenous people than the third - the imposition of the doctrine of discovery has an enduring significance for the denial of justice to Indigenous Australians. ${ }^{63}$ This begs the question of how the law applied the doctrine of

${ }_{61} \quad$ Mabo v Queensland (1992) 175 CLR 1 at 32, 37-38.

${ }_{62}$ Mabo v Queensland (1992) 175 CLR 1 at 32, per Brennan J, citing Evatt (1968), p 16, 'who mentions only cession and occupation as relevant to the Australasian colonies'.

63 If the land was terra nullius, all colonial law that was relevant to the colony would automatically apply, and Indigenous law would not be recognised and nor would Indigenous people necessarily be recognised. However, in the case of territory acquired through conquest or cession, the amount of colonial law applicable would be subject to the terms of any recognition of Indigenous law. Stated correctly the other way around, Indigenous law would be recognised subject to the terms of the conquest or cession 'agreement'. In Mabo v Queensland (1992) 175 CLR 1, Brennan J, at 34-35, quoted Blackstone's Commentaries, Book 1, Chapter 4, pp 106-08 to explain the rules governing the 'reception' of colonial laws into a colony (my emphasis): 'Plantations or colonies, in distant countries, are either such where the lands are claimed by right of occupancy only, by finding them desert and uncultivated, and peopling them from the mother-country; or where, when already cultivated, they have been either gained by conquest, or ceded to us by treaties. And both these rights are founded upon the law of nature, or at the least upon that of nations. But there is a difference between these two species of colonies, with respect to the laws by which they are bound. For it hath been held, that if an uninhabited country be discovered and planted by English subjects, all the English laws then in being, which are the birthright of every subject, are immediately there in force. But this must be understood with very many and very great restrictions. Such colonists carry with them only so much of the English law, as is applicable to their own situation and the condition of an infant colony ... What shall be admitted and what rejected ... must, in case of dispute, be decided at first instance by their own provincial judicature, subject to the revision and control of the King in council: the whole of their constitution being also liable to be new-modelled and reformed by the general superintending power of the legislature in the mother-country. But in conquered or ceded countries, that have already laws of their own, the king may indeed alter and change those laws; but, till he does actually change them, the ancient 
discovery to an already occupied territory, and on what basis it refuses to cure the deleterious effects of this error in contemporary times.

First, as Balibar and Wallerstein explain, international 'law' was a European construction aimed at avoiding war between colonial powers. ${ }^{64}$ That is to say, in the colonial era, the British, French, Dutch, Portuguese and other powers combined 'to forge the idea of "White" superiority, of civilization as an interest that has to be defended against the savages', and 'beyond this, all priding themselves, in competition with one another, on their particular humaneness, by projecting the image of racism on to the colonial practices of their rivals' ${ }^{65}$ In Mabo, Brennan J also spoke of the self-serving nature of the international law governing Australia's colonisation. ${ }^{66}$ Similarly, Fitzpatrick points out that international law developed with the rise of European imperialism as a means of resolving conflicts between colonisers as opposed to providing a system for justice or curtailing domination. ${ }^{67}$ International law was more a reflection of imperial power/force than a concern with justice.$^{68}$

laws of the country remain, unless such as are against the law of God, as in the case of an infidel country. Our American plantations are principally of this latter sort, being obtained in the last century either by right of conquest and driving out the natives (with what natural justice I shall not at present inquire) or by treaties. And therefore the common law of England, as such, has no allowance or authority there; they being no part of the mother-country, but distinct (though dependent) dominions. They are subject, however, to the control of the parliament.' Balibar and Wallerstein (1991), p 43.

65 Balibar and Wallerstein (1991), p 43.

${ }_{66}$ Mabo v Queensland (1992) 175 CLR 1 at 32: 'As among themselves, the European nations parcelled out the territories newly discovered to the sovereigns of the respective discoverers (66), provided the discovery was confirmed by occupation and provided the indigenous inhabitants were not organised in a society that was united permanently for political action. (67) To these territories the European colonial nations applied the doctrines relating to acquisition of territory that was terra nullius. They recognised sovereignty of the respective European nations over the territory of 'backward peoples' and, by State practice, permitted the acquisition of sovereignty of such territory by occupation rather than by conquest. (68)' The Original footnotes were: (66) Worcester $v$ Georgia (1832) 31 US 350, at 369; (67) Lindley, The Acquisition and Government of Backward Territory in International Law, (1926), Chs III \& IV; (68) See Lindley, p 47.

67 Fitzpatrick (2001), pp 156-57. It had its genesis in the peace settlement of the 1648 Peace (Treaty) of Westphalia which ended the Thirty Years War in Europe at that time.

${ }_{68}$ This was not lost on Brennan J, who quoted Blackstone's Commentaries on the Laws of England, 17 $7^{\text {th }}$ ed. (1830), Book II, Ch 1, p 7) in Mabo v Queensland (1992) 175 CLR 1 at 33 in this respect: 'But how far the seising on countries already peopled, and driving out or massacring the innocent and defenceless natives, merely because they differed from their invaders in language, in religion, in customs, in government, or in colour; how far such a conduct was consonant to nature, to reason, or to Christianity, deserved well to be considered by those, who have rendered their names immortal by thus civilizing mankind.' Still, the quote also reveals a definite sociobiological assumption that, in terms of the superior civilising the uncivilized, is the rhetoric of polygenesis, phrenology and social Darwinism. 
Second, the doctrine of discovery at international law could apply where the land was either wholly uninhabited or where an inhabited land was not 'organized in a society ... united permanently for political action' ${ }^{69}$ In other words, there was an 'enlarged notion of terra nullius' (also known as the 'barbarian theory'), allowing an otherwise inhabited territory to be treated as though it were uninhabited:

The hypothesis being that there was no local law already in existence in the territory ... Colonies of this kind were called 'settled colonies'. Ex hypothesi, the indigenous inhabitants of a settled colony had no recognised sovereign, else the territory could have been acquired only by conquest or cession. The indigenous people of a settled colony were thus taken to be without laws, without a sovereign and primitive in their social organization. ${ }^{70}$

In Mabo, Australia was recognised as being colonised according to this enlarged notion of terra nullius. ${ }^{71}$

Still, at international law, a further formal step was required before the doctrine of discovery could apply to confer territorial sovereignty on the coloniser. ${ }^{72}$ The law required an 'unequivocal act of appropriation' by the Crown to signal to others its intention to claim sovereignty. This unequivocal act had, for the two centuries prior to Australia's colonization, been marked in other places by mythic/religious procedures such as the planting of a Christian cross. ${ }^{73}$ Later approaches maintained similarities "with religious forms and justifications ... but the search for a legitimating basis of discovery shifted from the papal and religious to the monarchical and increasingly secular' ${ }^{74}$ In the Americas, Fitzpatrick claims this occurred through secular legal procedures. ${ }^{75}$ In Australia, the unequivocal act of

69 Mabo v Queensland (1992) 175 CLR 1 at 32.

70 Mabo v Queensland (1992) 175 CLR 1 at 36. As to the 'barbarian theory', it was premised on the idea that Indigenous inhabitants had no system of law, government, or appropriate use of land: see at 36, 39-40.

${ }^{71} \quad$ Mabo $v$ Queensland (1992) 175 CLR 1 at 37-38: 'Thus the theory which underpins the application of English law to the Colony of New South Wales is that English settlers brought with them the law of England and that, as the indigenous inhabitants were regarded as [at 38] barbarous or unsettled and without law, the law of England including the common law became the law of the Colony ...'

72 Dixon (1990), p 142 explains that: 'it is clear from the Island of Palmas Case [The Netherlands $v$ United States 2 RIAA (1928) 829] that discovery per se gives only an inchoate title to territory. This means that unless the first act of discovery is followed up within a reasonable period of time by acts of effective occupation, the potential title to territory accorded by discovery does not mature into full sovereignty.'

${ }^{73}$ Fitzpatrick (2001), p 162, citing Eliade (1965), pp 9-11): 'to the consecration of the new country, to a "new birth", thus repeating baptism (act of Creation).'

$74 \quad$ Fitzpatrick (2001), p 162.

75 Fitzpatrick (2001), p 163, citing Greenblatt (1991), p 56: 'Thus Columbus relied on papal authority, religious rituals of appropriation, and redemptive invocation, but his claims to the land in the name of the Spanish Crown were taken to be valid only when legally authorized by that sovereign power. Furthermore, Columbus usually insisted on 
appropriation was the arrival of the 'First Fleet' and the physical occupation of Governor Phillip in 1788 representing the clear intention of the Crown. ${ }^{76}$

These two legal steps (the discovery of uninhabited territory or territory inhabited by barbarians, and the unequivocal act of appropriation) necessary under the international doctrine of discovery allowing a coloniser to gain sovereignty were mutually reinforcing and racist. 'Discovery' was premised on racial superiority, while the 'unequivocal act of occupation' was premised upon racist ideas about what constitutes 'unequivocal' occupation, given that the indigenous inhabitants were already in occupation. This meant an act of appropriation through physical occupation was an option open to the Crown but not available to Indigenous Australians. This racist international law was repeated under common law because, after 1788 , squatters were able to acquire fee simple title through their physical occupation of the land, an option that was not available to Indigenous Australians already in occupation. ${ }^{77}$ In fact, this recognition of the squatters' occupation rights often rendered Indigenous people trespassers on their own land. ${ }^{78}$

Third, and importantly for the argument unfolding here, there had to be some justification for this colonial action, viz claiming sovereignty over territory inhabited by others. ${ }^{79}$ Although colonisation was an act of force, at both a legal and political level it required legitimation. ${ }^{80}$ In Mabo, Brennan $\mathrm{J}$ refers to two justifications for the acquisition of territory inhabited by 'backward peoples':

The benefits of Christianity and European civilization had been seen as a sufficient justification from mediaeval times. Another justification for the application of the theory of terra nullius to inhabited territory - a justification first advanced by Vattel at the end of the eighteenth century was that new territories could be claimed by occupation if the land were

some legalistic recording of discovery by a notary ... royal instruction of Spanish origin directed that "acts of possession" be made "before a notary public and the greatest possible number of witnesses"; also, "you shall make a gallows there, and have somebody bring a complaint before you, and as our captain and judge you shall pronounce upon and determine it".'

${ }^{76}$ Mabo $v$ Queensland (1992) 175 CLR 1 at 43. Brennan J rejected the proposition of Isaacs J in Williams $v$ Attorney-General (NSW) (1913) 16 CLR 404 at 439 that the moment of sovereignty was 'when Governor Phillip received his first Commission from King George III on 12 October 1786'. Per Deane and Gaudron JJ at 95: 'at the latest when Captain Phillip caused his second Commission to be read and published in the territory of the Colony'.

77 Mabo v Queensland (1992) 175 CLR 1 at 39-40: 'As the indigenous inhabitants of a settled colony were regarded as 'low in the scale of social organization', they and their occupancy of colonial land were ignored in considering title to land in a settled colony.'

78 Evans (1999), pp 2-25; Weaver (1996); Mabo v Queensland (1992) 175 CLR 1 at 69.

79 Law must be legitimate: Dixon (1990), pp 13-18; and the law needs both force and legitimation: Berns (1999), p 1.

so Berns (1999), p 1: 'I do not see how law can exist without force, at least for us, in our cultures. Once force is admitted, even insisted upon, the question of authority is posed. Force demands authority, for authority alone can legitimate its use, and without a certain kind of authority (or authorisation), force becomes illegitimate violence.' 
uncultivated, for Europeans had a right to bring lands into production if they were left uncultivated by the indigenous inhabitants. ${ }^{81}$

The first of these justifications (the benefits to others of Christian and European civilisation) fits with both monogenesis and polygenesis rhetoric. It is the idea that culturally superior Europeans could benefit 'backward' people through enlightenment. ${ }^{82}$ The second justification (advanced in the quote above by Vattel) is Locke's thesis that society prospers when land is cultivated and made productive rather than left to waste. ${ }^{83}$ Put another way, both the coloniser and the colonised would benefit if the latter's land is appropriated and made productive because society as a whole would prosper. ${ }^{84}$ This is the rhetoric of polygenesis in that some people were made inferior by God, and therefore 'the great white race' was entitled to take what was inhabited by 'lesser breeds' ${ }^{85}$ Both justifications found expression later in the writings of social Darwinists following Australia's colonisation in the sense that Indigenous people had not evolved to the same extent as Europeans. Hence colonisation could be justified on the basis that 'superior people and their ways' might be used to benefit others. ${ }^{86}$

Locke was also significant here in another sense. Locke positioned property as a right natural to men, but he also held that 'such rights could ... only be fully enjoyed by those who enter into a political society, the "Civiliz'd part of Mankind" such that it is the entry into political society which secures ownership - secures the land' ${ }^{87}$ Similar views were maintained by Hegel and Adam Smith, suggesting that by the eighteenth century it was axiomatic. ${ }^{88}$ There are two important points to note

81 Mabo v Queensland (1992) 175 CLR 1 at 32-33, references omitted. See also Fitzpatrick (2001), p 167.

82 Bernasconi (2002), pp 1-2.

83 Macpherson (1962), pp 211-12 quoting Locke: 'that he who appropriates land to himself by his labour, does not lessen but increase the common stock of mankind. For the provisions serving to the support of humane life, produced by one acre of inclosed and cultivated land, are ten times more, than those, which are yielded by an acre of land, of an equal richness, lying waste in common. And therefore he, that incloses land and has a greater plenty of the conveniences of life from ten acres, than he could have from an hundred left to nature, may truly be said, to give ninety acres to mankind.' Smith (1970), p 117.

Barta (2001), p 45.

Jones (1980), p 151.

Fitzpatrick (2001), p 165, quoting Locke.

In relation to Africa, Hegel commented in his Lectures on the Philosophy of World History that the: 'Negro ... exhibits the natural man in his completely wild and untamed state ... there is nothing harmonious with humanity to be found in this type of character', per Fitzpatrick (2001), p 122 quoting Hegel. Smith lived in the years from 1723 to 1790, and in his Wealth of Nations cites both Blackstone (Commentaries, 1765, pp 138, 491) and Locke: Smith (1970), pp 523-24. At p 104, Smith says that his first book in the Wealth of Nations is about the reason productivity is greater in some countries as opposed to less civilised ones. The reason, he claims, is attributable to the specialisation or degree of the division of labour. He also claims that this is the reason for the 'different ranks and conditions of men in the society'. 
here about Locke's 'natural law' theories. One is that he claimed to draw upon the laws of nature to justify private property rights using the premise that 'God gave everything to mankind in common' and that an individual could appropriate common property by mixing his labour with it. ${ }^{89}$ However, as Macpherson comments:

Locke's astonishing achievement was to base the property right on a natural right and natural law, and then to remove all the natural law limits from the property right. ${ }^{90}$

A second point is that Locke was able to justify his own participation in slavery, and hierarchical rights to sovereignty and property on the basis that 'some individuals, by a wilful turn against natural rights, can forever lose those natural rights'. ${ }^{91}$ On the one hand private property is a primitive right arising in the state of nature - 'it is a right which each individual brings to society in his own person, just as he brings the physical energy of his body' - and on the other hand, men only had rights when they were sufficiently 'civilised' to enter into political society. ${ }^{92}$ For Locke, natural rights were lost when one went against the natural law of development:

The waste landers ... have not joined the communal imaginings of 'European silver money,' with its specific codes of property, exchange value, and development. Hence 'great Tracts of Ground ... lie in waste, and are more than the People, who dwell on it, do, or can make use of, and so still lie in common'. Waste land is common land, according to this logic; and it awaits the virtuous energy of European developers, who may find themselves killing, enslaving, and philosophizing in the interests of development. ${ }^{93}$

Locke, like Francisco Vitoria before him, drew a distinction between men on the grounds of their capacity to enter into social agreements. ${ }^{94}$ In the sixteenth

${ }_{90} \quad$ Macpherson (1962), p 199.
Macpherson (1962), p 199.

${ }_{91} \quad$ Glausser (1990), p 214; see also Govier (1999), p 208, citing Carr (1913), pp 187, 188. Govier lists John Locke (FRS 1668) as a subscriber of the trade.

$92 \quad$ Sabine (1951), p 447.

$93 \quad$ Glausser (1990), p 215.

94 Glausser (1990), p 214. It isn't entirely clear, according to Glausser, whether Locke was discriminating on the basis of race or culture. On the one hand, Locke defined 'waste landers' as 'people who have not yet 'joined with the rest of mankind, in the consent of the Use of their common Money'. These are not beasts outside of common reason, then, but ... undeveloped in their failure to use money.' On the other hand, Glausser (at p 213) quotes Locke: 'First, a Child haveing framed the Idea of a Man, it is probable, that his Idea ... makes up the single complex Idea which he calls Man, whereof White or Flesh-colour in England being one, the Child can demonstrate to you, that a Negro is not a man', and further, 'A child unused to that sight \& haveing had some descriptions of the devil would call a Negro a devil rather than a Man \& at the same time call a dryl a man.' 
century, the international jurist Vitoria had argued that the 'Indian' was a human being with natural rights and therefore the right to dominium (property). ${ }^{95}$ This did not necessarily mean that the 'Indian' had a right to imperium (sovereignty), just the capability for the ownership of property. By the eighteenth century, Vitoria's argument had waned such that non-Occidental societies were deemed uncivilised and therefore incapable of both imperium and dominium..$^{96}$

It is clear that Locke justified unjust social relations by claiming to interpret natural law about the place of humans in nature and the nature of humans. This is sociobiological reasoning, and Locke's views became hegemonic in common law countries. So influential were Locke's ideas about people, political systems and property that:

a Select Committee on Aborigines reported in 1837 to the House of Commons that the state of Australian Aborigines was 'barbarous' and 'so entirely destitute $\ldots$ of the rudest forms of civil polity, that their claims whether as sovereigns or proprietors of the soil, have been utterly disregarded. ${ }^{97}$

These views prevailed in Australian law as justifications for the denial of Indigenous sovereignty and property rights between 1788 and 1992 until the Mabo case addressed the issue of property rights. ${ }^{98}$

There, the High Court rejected the applicability of an expanded doctrine of terra nullius, declaring 'the basis of the theory is false in fact and unacceptable in our society'. ${ }^{9}$ However, in removing the legal basis for colonisation, the door was not left open for an Indigenous claim to sovereignty. Rather, Mabo, incorporated a judicial 'sleight of hand' to deliver mixed justice for Indigenous people. ${ }^{100}$ This was because Mabo simultaneously recognised native title and that the doctrine of terra nullius was a fiction, yet denied the possibility for any Indigenous sovereignty. The rationale for this sleight of hand was that a common law court could not decide sovereignty because that is the province of international law. ${ }^{101}$ Fitzpatrick

95 Fitzpatrick (2001), p 163. Vitoria had argued that the Natives of America were children of God, and hence had vested in them natural rights.

$96 \quad$ Fitzpatrick (2001), p 157.

${ }_{97} \quad$ Mabo v Queensland (1992) 175 CLR 1 at 40, reference omitted.

98 Dorsett (1998).

99 Mabo v Queensland (1992) 175 CLR 1 at 40.

100 See, for example, Mansell (1992).

${ }_{101}$ Mabo v Queensland (1992) 175 CLR 1 at 33: 'However, that may be, it is not for this court to canvass the validity of the Crown's acquisition of sovereignty over the Islands which, in any event, was consolidated by uninterrupted control of the Islands by Queensland authorities'; and at 44: 'The acquisition of territory is chiefly the province of international law; the acquisition of property is chiefly the province of the common law.' 
condemns what he refers to as the law's 'legerdemain' in the violent structuring of hierarchy since the law claims it is at once active but at the same time passive. ${ }^{102}$

Sovereignty for Indigenous Australians is beyond the realm of legal possibilities. Australia's highest court asserts a lack of jurisdiction to determine the question of British and Australian sovereignty because that is the domain of the International Court of Justice. Indigenous Australians are unlikely to obtain a favourable declaration from the International Court of Justice because, as a general proposition, they would not be able to attract that court's jurisdiction, ${ }^{103}$ and even if they did:

They would be unsuccessful because the Court would apply the international law of the late $18^{\text {th }}$ century (under which the acquisition of Australia was lawful), not contemporary standards. This approach is known as the 'doctrine of intertemporal law'. Similarly, although contemporary human rights standards guarantee the right of 'self-determination' to 'all peoples', the United Nations Human Rights Committee has refused to entertain complaints by indigenous people about denial of this right. ${ }^{104}$

Therefore, Australian law has maintained the original sociobiological argument for the deprivation of Indigenous sovereignty. The eighteenth century sociobiological justification for seizing territory (viz that Europeans could make better use of land than inferior savages who wasted the land) survives as good Australian law in the twenty-first century.

\section{Dispossession}

Australia was not the 'peaceful settlement' the socially and legally constructed myth deemed it to be. ${ }^{105}$ The period immediately after the 1788 arrival of the 'First Fleet' was a time marked by a mixture of extreme violence and benevolence toward Indigenous people as they were systematically dispossessed of their land:

Anyone still ignorant of the discourse of genocide which accompanied the European acquisition of Aboriginal land can be referred to the historical

102 Fitzpatrick (2001), p 171: 'The necessary unknowing is revealed here not as a disregard of law's coming into being historically, "back then", but as a denial of both the iterant violence of law now in being and the responsibility which recognition of that violence would inexorably import.'

${ }_{103}$ Clarke (1997), p 248, citing Balkin (1988), pp 31-32: 'indigenous citizens of independent nation states cannot invoke that Court's jurisdiction. Unless they secure the assistance of the United Nations General Assembly or Security Council in procuring a non-binding advisory opinion - a very unlikely outcome in the Australian case.'

104 Clarke (1997), p 258, citing Lubicon Lake Band $v$ Canada UN Doc CCPR/C/38/D167/1984, 28 March 1990 and Mikmaq Tribal Society v Canada UN Doc CCPR/C/39/D/205/1986/, 21 August 1990. 
record. The blood-curdling proclamations of frontier journals have been republished progressively over the past thirty years. ${ }^{106}$

And:

Genocide was never the policy of the state. It could be argued it was the effectual policy of the state, because so little was done to restrain the settlers. Certainly, protectors were appointed, and severe warnings issued. But only in a few cases were perpetrators of a massacre brought to justice. ${ }^{107}$

This ambiguity arose because the colonial mission itself was contradictory. That is to say, the colonisers sought to uphold the liberal ideal of 'individuality' (which assumes equality before the law), and at the same time they sought to establish a colony on land already inhabited (which meant the dispossession of the local inhabitants of their land, their rights and their sovereignty).

From the beginning, the colonisers expressed ambivalence in the official instructions to Governor Phillip. Instructions contained a mixture of concern for the colonised with an intention to take their land:

[The Governor should use] full power and authority to agree for such lands tenements and hereditaments as shall be in our power to dispose of and grant them to any person or persons ... You are to endeavour by every possible means to open an intercourse with the natives, and to conciliate their affections, enjoining all our subjects to live in amity and kindness with them. And if any of our subjects shall wantonly destroy them, or give them any unnecessary interruption in the exercise of their several occupations, it is our will and pleasure that you do cause such offenders to be brought to punishment according to the degree of the offence. ${ }^{108}$

Official policies and orders from imperial sources continued thereafter to express a desire to protect Indigenous people while also providing for the systematic dispossession of Australian Aborigines. ${ }^{109}$

Colonisation inevitably meant violence would be necessary to ensure that the Indigenous people were dispossessed of their land while the legal system invented fictions to legitimise the new property regime, masking the crime and simultaneously protecting its own integrity. ${ }^{110}$ One of these fictions was the adoption of terra nullius. Another was the rejection of terra nullius as the basis for sovereignty and the simultaneous acceptance of the doctrine of tenure, which was

\footnotetext{
$106 \quad$ Barta (2001), p 41.

${ }_{107}$ Barta (2001), p 42.

108 Mabo v Queensland (1992) 175 CLR 1 at 96, per Deane and Gaudron JJ.

109 Weaver (1996), p 984.

110 As 'squatters' steadily dispossessed Indigenous people from their land, they would then lobby colonial authorities to legitimise their land grab. Authorities most often acquiesced to these demands and granted various forms of title, ranging from licences to leases to freehold title. See further Weaver (1996).
} 
much less an Australian fiction than it was one of English history. ${ }^{111}$ In Mabo, Brennan $\mathrm{J}$ justified this judicial choice on the basis that to do otherwise would 'fracture a skeletal principle of our legal system'."12 Yet another of these fictions was the categorisation of Indigenous people as being beyond the law. ${ }^{113}$ This fiction regarded Indigenous people as beyond the law in terms of rights but within the law in terms of control. In other words, Indigenous people were on the one hand human, but on the other hand less than human - they were 'savages' or 'uncivilised'. This crude type of sociobiological reasoning assumed, according to monogenism, that Indigenous people, although descended from Adam and Eve, had not progressed beyond a savage state because of their culture. ${ }^{114}$ Alternatively, polygenism held that these people were sub-human because they did not descend from Adam and Eve but were instead descendants of an inferior race incapable of progress. ${ }^{115}$ In either case, Indigenous Australians had been deemed savages according to a crude type of sociobiological reasoning. In fact, the judiciary has sought to distance itself from this violent episode in Australian history by blaming the state rather than the courts:

\begin{abstract}
Aboriginals were dispossessed of their land parcel by parcel, to make way for expanding colonial settlement. Their dispossession underwrote the development of the nation. [I]t is appropriate to identify the events which resulted in the dispossession of the indigenous inhabitants of Australia, in order to dispel the misconception that it is the common law rather than the action of governments which made many of the indigenous people of this country trespassers on their own land. ${ }^{116}$
\end{abstract}

And:

Sovereignty carries the right to extinguish private rights and interests in land within the sovereign territory. It follows that on a change of sovereignty, rights and interests in land that have been indefeasible, under the old regime become liable to extinction by exercise of the new sovereign power. The sovereign power may or may not be exercised with solicitude for the welfare of indigenous inhabitants, but in the case of common law countries, the courts cannot review the merits as distinct from the legality of the exercise of sovereign power. ${ }^{117}$

111 The fiction applied to both countries was that land was not originally granted by the Crown: Mabo v Queensland (1992) 175 CLR 1 at 47.

$112 \quad$ Mabo v Queensland (1992) 175 CLR 1 at 43 and 45.

$113 \quad$ Barta (2001), p 44.

114 Bernasconi (2002), pp 1-8; Haller (1970). Although there was no singular monogenist view because it was used ideologically to promote racism and resist it.

115 Bernasconi (2002), pp 1-8; Haller (1970). Again, like their monogenist adversaries, the polygenists were divided into racist and non-racist views and so there was no single polygenist view.

$116 \quad$ Mabo v Queensland (1992) 175 CLR 1 at 69.

$117 \quad$ Mabo v Queensland (1992) 175 CLR 1 at 63. 
In other words, as Fitzpatrick has argued, the law was passive in relation to political issues while at the same time the law actively robbed Indigenous people of their sovereignty. ${ }^{118}$ Yet it is clear from the earlier cases - and indeed Mabo itself - that the courts were active in the dispossession of Indigenous people from their lands. ${ }^{119}$

Because massacres, disease and dispossession had reduced the Indigenous population so drastically in such a short time, the public policy shifted to a more benevolent view towards the 'doomed race'. ${ }^{120}$ One example of this shift was the colonial administration's requirement that pastoral leases contain an express reservation in favour of Indigenous peoples. ${ }^{121}$ This shift also marked the beginning of what is referred to as the 'protection era' of administration, law and policy.

118 Fitzpatrick (2001), p 170-71, citing Marshall CJ in Johnson v McIntosh (1823) 21 US 240 (8 Wheat 543).

119 Two relatively early cases failed Indigenous people. In the case of Attorney-General $v$ Brown (1847) 1 Legge 312, at 316-18, Stephen CJ recognised that property of the land in the Crown was 'doubtless' a 'fiction', but nevertheless ruled that all unoccupied land belonged to the Crown because, 'there would be no other proprietor'. Just over 100 years after the First Fleet arrived, Cooper v Stuart reached the Privy Council. Despite an abundance of documentary evidence to the contrary at that time, the 'barbarian theory' of the doctrine of terra nullius was applied, viz New South Wales was 'without settled inhabitants or settled law': per Lord Watson in Cooper $v$ Stuart (1889) 14 App Cas at 291. While in Mabo v Queensland (1992) 107 ALR 1, per Deane and Gaudron JJ at 82: 'Inevitably, one is compelled to acknowledge the role played, in dispossession and oppression of the Aboriginals, by the two propositions that the territory of New South Wales was, in 1788, terra nullius in the sense of unoccupied or uninhabited for legal purposes and that full legal and beneficial ownership of all lands of the Colony vested in the Crown, unaffected by any claims of the Aboriginal inhabitants. Those propositions provided a legal basis for and justification of the dispossession. They constituted the legal context of the acts done to enforce it and, while accepted, rendered unlawful acts done by the Aboriginal inhabitants to protect traditional occupation or use. The official endorsement, by administrative practice and in judgments of the courts, of those two propositions provided the environment in which the Aboriginal people of the continent came to be treated as a different and lower form of life whose very existence could be ignored for the purpose of determining the legal right to occupy and use their traditional homelands.'

120 Evans (1999), p 118; and Barta (2001), p 44 (quoting Broome 1995): 'while the efforts of missionaries and protectors saved the remnant for possible regeneration, the later determination of governments to shed responsibility for all but the small number of "full-bloods" meant that assimilation was expected to bring about the disappearance of the problem. By the 1920 s, estimates ranged from 402 to 586 survivors, "a point dangerously close to the extinction of a people".'

121 This reservation, along with several other reservations in favour of third parties ultimately assisted the Wik People in their claim that pastoral leases were not synonymous with common law leases since these reservations were antithetical to the notion of 'exclusive possession' (a defining feature of common law leases), rendering pastoral leases more akin to licences and therefore not incompatible with native title. See further Wik Peoples $v$ Queensland (1996) 187 CLR 1. 


\section{Protection to Responsibility}

What is otherwise known as the 'protection' era arose as an imperial parliamentary response to the catastrophic decline in the Indigenous population. It was a reaction to reports of massacre, murder, disease and dispossession. ${ }^{122}$ The protection era represents the period ranging from the late nineteenth century through until the 1970s. 'Protection' was an official policy aimed at 'protecting' the survivors of colonisation and dispossession. Instead, the protection era harboured the exploitation of Indigenous labour, the removal of children from their families, strict controls over marriage, and the brutal abuse of internees in reserves and institutions. ${ }^{123}$ Under the broad banner of 'protection', there were at least three discernible policy shifts commencing with 'merging' in the 1890 s through to 'absorption' from 1937 and further forward until 'integration' in the 1960s. ${ }^{24}$ Despite the nuances, for Murphy these policy shifts falling under the banner of 'protection' were all aimed at one over-arching objective: the assimilation of Indigenous people into 'white Australia'. ${ }^{125}$ McPhee corroborates Murphy's thesis, claiming that assimilation was strongly recommended in 1896 by Baldwin Spencer (Professor of Biology at the University of Melbourne) and Frank Gillen (SubProtector of Aborigines in Alice Springs) following their fieldwork in central Australia. ${ }^{126}$ Spencer was also an important government adviser who was later appointed as Chief Protector of Aborigines in the Northern Territory in 1911, and reportedly advised the government that:

No half-caste children should be allowed to remain in any native camp ... even though it may seem cruel to separate the mother and child, it is better to do so. ${ }^{127}$

The first model for the protection regime, 'merging', was the result of an inquiry by a Select Committee established by the Imperial Parliament to investigate the 'condition of Aboriginal people' after reports had filtered through to London about the 'massacres and atrocities' taking place in the 1800s. ${ }^{128}$ Among its recommendations:

122 Barta (2001), pp 44, 50: 'In Australia assimilationist talk was developed over more than 50 years to cope with the results of colonisation and genocide.'

${ }_{123}$ Saunders and Evans (1992), pp 42-53; and generally Bringing Them Home (1997).

$124 \quad$ Bringing Them Home (1997), pp 22-30.

${ }_{125}$ Murphy (2000), p 7: 'At the end of it all, Aboriginal people are still dealing with institutions and processes that are imposed. Not only are these institutions and processes inadequate to Aboriginal culture and experience, they perpetuate the process of colonisation. The mechanism through which this domination is currently maintained is the participatory fora of a managerialist model of public administration. Although these for a represent a shift from an earlier model, which operated in a context of conflict, to a model that now operates in a context of 'consensus', the administrative practice of terra nullius in social policy prevails.'

126 McPhee (1999), p 10.

127 McPhee (1999), p 10, quoting Wolfe (1999).

${ }_{128}$ Bringing Them Home (1997), pp 22-23. 
The Select Committee Inquiry proposed the establishment of a protectorate system, noting that 'the education of the young will of course be amongst the foremost of the cares of the missionaries; and the Protectors should render every assistance in their power in advancing this all-important part of any general scheme of improvement' (quoted by Victorian Government final submission on page 25). The protectorate system was based on the notion that Indigenous people would willingly establish self-sufficient agricultural communities on reserved areas modelled on an English village and would not interfere with the land claims of the colonists. ${ }^{129}$

In Queensland, Indigenous people were managed through legislation passed between 1897 and 1934 called The Aborigines Protection and Restriction of the Sale of Opium Act and The Aboriginals Preservation and Protection Act of 1939. This legislation regulated everything from sexual intercourse to the partial denial of citizenship rights. ${ }^{130}$ In other states, the laws were equally repressive:

The government response was to reserve land for the exclusive use of Indigenous people and assign responsibility for their welfare to a Chief Protector or Protection Board. By 1911 the Northern Territory and every State except Tasmania had 'protectionist legislation' giving the Chief Protector or Protection Board extensive power to control Indigenous people. In some States and in the Northern Territory the Chief Protector was made the legal guardian of all Aboriginal children, displacing the rights of parents. The management of the reserves was delegated to government appointed managers or missionaries in receipt of government subsidies. Enforcement of the protectionist legislation at the local level was the responsibility of 'protectors' who were usually police officers. In the name of protection Indigenous people were subject to near-total control. Their entry to and exit from reserves was regulated as was their everyday life on the reserves, their right to marry and their employment. With a view to encouraging the conversion of the children to Christianity and distancing them from their Indigenous lifestyle, children were housed in dormitories and contact with their families strictly limited. ${ }^{131}$

By the 1930s, it had become clear that the policy of 'merging' had failed as the general public had found the remaining 'diseased and suffering' Indigenous people 'unsettling', and governments 'typically viewed Indigenous people as a nuisance'. ${ }^{132}$ While the 'full-bloods' had not died out as expected, they were in decline and still

Bringing Them Home (1997), p 23.

Evans (1999), pp 118-19: 'Thus, the 1890s creation of special social control agencies, exemplified in the offices of Chief Protector, Police Protector, Reserve and Mission Superintendent, and Matron, with near total powers over apprehended Aborigines, as well as the phenomenon of the reserve/mission itself as a closed, correctional and custodial institution, were the logical extensions of contaminatory public anxieties into the official domain.'

131 Bringing Them Home (1997), p 23.

132 Bringing Them Home (1997), p 23. 
breeding; at the same time, the mixed-descent population continued to grow. ${ }^{133}$ Then in 1937, following the 'first Commonwealth-State Native Welfare Conference', the 'Aboriginal problem' was reconsidered:

Discussion was dominated by the Chief Protectors of Western Australia, Queensland and the Northern Territory: A.O. Neville, J.W. Bleakley and Dr Cook respectively. Each of them presented his own theory, developed over a long period in office, of how people of mixed descent would eventually blend into the non-Indigenous population. The conference was sufficiently impressed by Neville's idea of 'absorption' to agree that,

$\ldots$ this conference believes that the destiny of the natives of aboriginal origin, but not of the full blood, lies in their ultimate absorption by the people of the Commonwealth, and it therefore recommends that all efforts be directed to that end.

In relation to Indigenous children, the conference resolved that:

... efforts of all State authorities should be directed towards the education of children of mixed aboriginal blood at white standards, and their subsequent employment under the same conditions as whites with a view to their taking their place in the white community on an equal footing with the whites. ${ }^{134}$

This marked a shift in protection policy from 'merging' to 'absorption'. The subtle difference in terms masks an escalation in the laws and procedures aimed at assimilation and the forced removal of children from their families:

Whereas 'merging' was essentially a passive process of pushing Indigenous people into the non-Indigenous community and denying them assistance, assimilation was a highly intensive process necessitating constant surveillance of people's lives, judged according to non-Indigenous standards. ${ }^{135}$

Assimilationist policies under the rubric of 'protection' were sociobiological in at least three respects. First, these policies were based on polygenesis:

Of course, polygenism provided a powerful rationale for treating blacks both as vermin and as chattel labour, and for warning against European sexual intermixture and especially inter-marriage with Aborigines, Melanesians or Chinese. But its functional role, in popular or folk racism, extended in Queensland society well into the twentieth century. ${ }^{136}$

Second, eugenics was a significant sociobiological influence on the policies used from the 1890s up until the 1970s. Scott points to a critical text informing

\footnotetext{
${ }_{133}$ Bringing Them Home (1997), $\mathrm{p} 24$.

${ }_{134}$ Bringing Them Home (1997), p 26, emphasis added.

${ }_{135} \quad$ Bringing Them Home (1997), $\mathrm{p} 27$.

136 Evans (1999), pp 41-42.
} 
government policy called Australia's Coloured Minority: Their Place in Our Community by AO Neville, published in 1948:

The scientist, with his trained mind and keen desire to exert his efforts in the field investigating native culture and in studying the life history of the species, supplies an aid to administration. ${ }^{137}$

The 'administration' referred to by Neville in this passage was the management and control of Indigenous people, and the science informing him was eugenics:

What sort of science? Well, eugenics mostly. That is: 1. the science of improving the qualities of the human race, esp. the careful selection of parents. 2. The science of improving offspring. (The Macquarie Dictionary)

You could read it in the newspapers, too:

The modern world has many problems to face. The half-caste is not one of them. He or she is merely a passing phase, an incident in history, an interesting event in what we call 'progress'... He will solve himself and disappear. That much is certain, it is not problematical. The only problem that enters into it, though it is a palpable misuse of the word to call it that, is how long it is going to take. A few centuries maybe, perhaps much less ... on the ground that he is a nuisance to us, we should hurry on his disappearance.

Third, assimilation is also a form of social Darwinism. ${ }^{139}$ It is the idea that the inferior culture would not survive competition with the superior culture and therefore should be not sustained by artificial means. This mandated selfsufficiency so that Indigenous men, women and children had to work for their rations rather than receive 'sit-down' money. ${ }^{140}$ It also justified their exploitation as forced labour as they helped to build the nation. ${ }^{141}$

Despite the oppression caused by this tightening of control, Indigenous people survived and initiated political struggles against it. ${ }^{142}$ The policy of 'absorption' failed to assimilate Indigenous people into 'white Australia'. ${ }^{143}$ Indigenous struggles

$137 \quad$ Scott (2001), p 2.

138 Scott (2001), pp 2-3, quoting the West Australian in 1933.

139 Evans (1999), p 198: 'For although their physical lives may have been spared, their social lives, in a society which both despised them and fully endorsed the white master's coercive controls, were not.'

140 Saunders and Evans (1992), pp 53-56, 406-07.

${ }_{141}$ Grimshaw et al (1996), pp 198, 234.

142 Evans (1999), pp 178, 233.

143 Bringing Them Home (1997), p 28. Newly appointed liberal party Minister for Territories Paul Hasluck commented at the 1951 Native Welfare Conference 'that Australia's treatment of its indigenous people made a mockery of its promotion of human rights at the international level'. As a result, the conference decided that assimilation was essential: 'Assimilation means, in practical terms, that, in the course of 
culminated in the 1967 Referendum and changes to the Constitution to allow the Commonwealth to legislate on behalf of Indigenous people. ${ }^{144}$ These same pressures brought to bear a symbolic shift in policy over this same period of time, from 'absorption' to 'integration'. ${ }^{45}$

Then, in 1972, the Whitlam government responded to the by then growing, political action of Indigenous people to initiate a further shift in policy, 'selfmanagement' aimed ultimately at 'self-determination'. ${ }^{146}$ As a step in this direction, the Whitlam government made a number of reforms including the introduction of the Race Discrimination Act 1975 (passed subsequently by the Fraser government), the creation of a National Aboriginal Consultative Committee in 1973, an Aboriginal Loans Commission in 1974, and the introduction of statutory land rights into the Northern Territory. ${ }^{147}$ Since then, there have been only two changes to public policy despite major inquiries and several CERD reports criticising Australian governments for the failure to address Indigenous incarceration, deaths in custody, poverty, disease and ill-health, and unemployment. ${ }^{148}$ The two notable exceptions were the establishment of the Aboriginal and Torres Straight Islander Commission in 1989 and its controversial demise in 2004, arguably representing a shift back to the policy of 'integration'. ${ }^{149}$

In this period - often seen as commencing with the initiatives of the Whitlam government through to the present day - there were two important changes. The first change was the establishment of bureaucracies, which to varying degrees included Indigenous representation. ${ }^{150}$ The second set of changes was legal in

time, it is expected that all persons of aboriginal blood or mixed blood in Australia will live like other white Australians do.'

144 The 1967 Referendum amended section 51(26) of the Constitution, which previously prevented the Commonwealth Parliament from legislating for the people of any race, 'other than the aboriginal race in any state'. The quoted words were removed: Constitution Alteration (Aboriginals) Act (No 55) 1967.

145 Bringing Them Home (1997), p 28. As a result, a 'federal Office of Aboriginal Affairs was established and made grants to the States for Aboriginal welfare', and "Assimilation" was discarded as the key term of Aboriginal policy in favour of "integration".'

146 Grimshaw et al (1996), pp 302-03, 306-07, 312; Evans (1999), pp 114-15; and ATSIC (1990).

147 ATSIC (1990).

148 For instance: Royal Commission into Aboriginal Deaths in Custody (1991); and Committee on the Elimination of Racial Discrimination, 53rd Session (3-21 August 1998), CERD/C/53/Misc.17/Rev.2, [1998] AILR 42, (1998) 3 AILR 590.

According to the 2004 Social Justice Report (of the HREOC Aboriginal and Torres Strait Islander Social Justice Commissioner), as a result of the 2004 enactment of the ATSIC Amendment Act: "Under the new arrangements, "more than $\$ 1$ billion of former ATSIC-ATSIS programs was transferred to mainstream departments". These departments will be required to "accept responsibility for Indigenous services" and be "held accountable for outcomes". The transfer of Indigenous service to mainstream departments aims to ensure that departments will "work in a coordinated way" and "to make sure that local families and communities have a real say in how money is spent".'

150 Saunders and Evans (1992), pp 412-13. 
nature, beginning with the enactment of the Racial Discrimination Act 1975, and later the series of cases concerning Indigenous issues in the wake of the 1992 Mabo case.

Why is this sociobiological? Because the legal and institutional arrangements since 1975 have obscured responsibility for the condition of Indigenous Australians by deeming them responsible for their circumstances while denying selfdetermination. ${ }^{151}$ These policy changes have encouraged increased Indigenous representation into 'white' institutions as a new approach to management of the 'Aboriginal problem', giving the impression of reform and allowing the blame for Indigenous people's conditions to extend to Indigenous leadership. ${ }^{152}$ This has the effect of naturalising the past and naturalising the status quo, where instead the 'white' acceptance of responsibility for past injustice together with selfdetermination would initiate substantive justice. It is precisely a lack of desire for substantive justice that makes it necessary to justify the status quo according to sociobiology.

Over time, the sociobiological presumption that the inferior and doomed race would be wiped out, first through dispossession and then later through policies aimed at selective breeding, proved incorrect:

The violence and disease associated with colonisation was characterised, in the language of social Darwinism, as a natural process of 'survival of the fittest'. According to this analysis, the future of Aboriginal people was inevitably doomed; what was needed from governments and missionaries was to 'smooth the dying pillow'. ${ }^{153}$

Subtle changes to prevailing sociobiological ideas led to changes in policy, but policy and law were always linked to the power interests of a growing economy. For this reason, the policy maintained hierarchies on the basis of race and class (and gender) ${ }^{154}$ throughout the period from 1788 to the present. That is to say, initially Indigenous people were seen as an impediment to the colonial 'land grab', and later a different hierarchal relationship was required to build the nation. ${ }^{155}$ This 'management' of Indigenous Australians was achievable only through a myriad of sociobiological laws aimed at differentiating between indigenous people and white Australians on the basis of blood, skin colour and genes. ${ }^{156}$

151 Here sociobiology facilitates the reification of the 'problem'. It shifts responsibility from the perpetrator and blames the victim by attributing circumstances to innateness.

152 Murphy (2000).

153 Bringing Them Home (1997), p 23.

154 See generally Saunders and Evans (1992).

155 Foucault (1979a); Foucault (1979b), pp 139-40. In Foucault's terms, the subjects now needed to be managed by their masters, marking a shift in sovereignty from the power over life and death to a power to manage.

156 Bringing Them Home (1997), p 25 (citing McCorquodale (1987), p 9). The report noted that the term 'Aboriginality' had more than 67 definitions contained in 700 pieces of legislation. 


\section{Conclusion}

Sociobiology underpinned, and continues to underpin, the colonisation, dispossession, control, domination and oppression of Indigenous Australians. Colonisation was made possible by the fiction of the doctrine of terra nullius, which was sociobiological because it made assumptions about the place of humans in nature and about the nature of humankind, and then used these assumptions as an excuse for hierarchy and domination. Once Australia had been taken as terra nullius, the sociobiological justification was invoked to underscore government policy. This time the argument was that the Indigenous people were a 'doomed race', destined to lose the struggle for survival with a more advanced civilised race. ${ }^{157}$ This meant the herding of people off their traditional lands into 'reserves', where they were either categorised as unfit for use as cheap labour, or exploited in Australian industry or made domestic servants in private homes. Later, by the 1970s after a long struggle for justice, Indigenous people began to receive limited recognition in the guise of law reform and bureaucratic reform. However, this recognition afforded no 'self-determination', and was instead aimed at ensuring Indigenous people were held responsible for their circumstances, while exculpating colonial responsibility and ensuring that the Australian nation was a good human rights citizen. This period delivered formal rights, which essentially reasserted the status quo and therefore 'naturalised' the 'Aboriginal problem' as inevitable, incurable, irreconcilable and innate. Therefore, it too is a period marked by sociobiological ideology.

\section{References}

\section{Secondary Sources}

Aboriginal and Torres Straight Islander Commission (1990) Twenty-five Years On, ATSIC.

Richard D Alexander (1975) 'The Search for a General Theory of Behaviour' 20 Behavioral Science 77.

Alan Ardill (2008) Sociobiology and Law, PhD thesis, Griffith University, www4.gu.edu.au:8080/adtroot/public/adt-QGU20081103.141615/index.html.

Christopher Badcock (1991) Evolution and Individual Behaviour, Basil Blackwell.

Christopher Badcock (2000) Evolutionary Psychology: A Critical Introduction, Polity Press.

Etienne Balibar and Immanuel Wallerstein (1991) Race, Nation, Class: Ambiguous Identities, Verso.

Rosalie Balkin (1988) 'International Law and Sovereign Rights of Indigenous Peoples' in B Hocking (ed), International Law and Aboriginal Human Rights, Law Book Co.

Tony Barta (2001) 'Discourses of Genocide in Germany and Australia: A Linked History' 25 Aboriginal History 37.

Robert Bernasconi (ed) (2002) 'Introduction', in American Theories of Polygenesis, Thoemmes Press. Sandra Berns (1999) To Speak as a Judge: Difference Voice and Power, Ashgate.

Bringing Them Home: National Inquiry into the Separation of Aboriginal and Torres Strait Islander Children from Their Families, 26 May 1997.

157 Evans (1999), p 118: "white Australians clung hopefully at the time to the eugenically pristine promise of the "Doomed Race" theory, which held that "full blood" Aborigines would naturally become extinct, while the spread of a "half-caste" population was to be firmly thwarted administratively.' 
C Carr (1913) Selected Charters of Trading, Seldon Society.

Jennifer Clarke (1997) 'Law and Race: The Position of Indigenous People' in S Bottomley and S Parker (eds), Law in Context, Federation Press.

Bruce Dain (2004) 'Was there a Transition to Modern Racism in Antebellum America? A Reappraisal', paper delivered at the American Studies Association Annual Meeting, University of Utah, 11 November.

Charles Darwin (1859) On the Origin of Species by Means of Natural Selection or the Preservation of Favoured Races in the Struggle For Life, 2nd ed, Modern Library.

Charles Darwin (1871) The Descent of Man and Selection in Relation to Sex, John Murray.

Loretta de Plevitz and Larry Croft (2003) 'Aboriginality Under the Microscope: The Biological Descent

Test in Australian Law' 3(1) Queensland University of Technology Law \& Justice Journal 1.

Shauna Dorsett (1998) 'Land Law and Dispossession: Indigenous Rights to Land in Australia' in

S Bright and J Dewar (eds), Land Law: Themes and Perspectives, Oxford University Press.

Martin Dixon (1990) Textbook on International Law, 3rd ed, Blackstone.

Robin Dunbar (2005) Evolutionary Psychology: A Beginner's Guide, Oneworld.

Jason Edwards (2003) 'Evolutionary Psychology and Politics’ 32(2) Economy \& Society 280.

Riane Eisler and Daniel S Levine (2002) 'Nurture, Nature, and Caring: We are Not Prisoners of Our Genes' 3 Brain and Mind 9.

Raymond Evans (1999) Fighting Words: Writing About Race, University of Queensland Press.

Elizabeth Evatt, 'The Acquisition of Territory in Australia and New Zealand' in (1968) Grotian Society Papers, p. 16

Shulamith Firestone (1972) The Dialectic of Sex: The Case for Feminist Revolution, Granada.

Peter Fitzpatrick (2001) Modernism and the Grounds of Law, Cambridge University Press.

Michel Foucault (1979a) 'Governmentality’ 6 Ideology and Consciousness 5.

Michel Foucault (1979b) The History of Sexuality, Volume 1: An Introduction, trans R Hurley, Penguin.

Martin Flynn and Sue Stanton (2000) 'Trial by Ordeal: The Stolen Generation in Court' 25(2) Alternative Law Journal 75.

Jeremy Freese and Brian Powell (2001) 'Making Love Out of Nothing at All? Null Findings and the Trivers-Willard Hypothesis' 106(6) The American Journal of Sociology 1776.

Wayne Glausser (1990) 'Three Approaches to Locke and the Slave Trade' 51(2) Journal of the History of Ideas 199.

Stephen Jay Gould (1991) Ever Since Darwin: Reflections in Natural History, Penguin.

Mark Govier (1999) 'The Royal Society, Slavery and the Island of Jamaica: 1660-1700' 53(2) Notes and Records of the Royal Society of London 203.

Marjorie Grene and David Depew (2004) The Philosophy of Biology: An Episodic History, Cambridge University Press.

Patricia Grimshaw, Marilyn Lake, Ann McGrath and Marian Quartly (1996) Creating a Nation, Penguin.

John S Haller (1970) 'The Species Problem: Nineteenth-Century Concepts of Racial Inferiority in the Origin of Man Controversy' 72 American Anthropologist 1319.

Donna Haraway (1991) Simians, Cyborgs, and Women: The Reinvention of Nature, Routledge.

Linda Hirshman (1998) 'Hard Bargains: The Politics of Heterosexuality' 55(1) Washington \& Lee Law Review 185.

John Hochman (1992) 'The Divine Archetype: Sociobiology and the Psychology of Religion' 149(7) The American Journal of Psychiatry 974.

Richard Hofstadter (1959) Social Darwinism in American Thought, rev ed, George Braziller.

Constance Holden (1996) “'Sociobiology” to History’s Dustbin?’ 273 Science 315.

Gerald Holton (1998) 'The New Synthesis’ 35(2) Society 1978. 
Greta Jones (1980) Social Darwinism and English Thought: The Interaction Between Biological and Social Theory, The Harvester Press.

Paul A Lombardo (1996) 'Medicine, Eugenics, and the Supreme Court: From Coercive Sterilization to Reproductive Freedom' 13 Journal of Contemporary Health Law and Policy 1.

CB Macpherson (1962) The Political Theory of Possessive Individualism: Hobbes to Locke, Oxford University Press.

Thomas Malthus (1960 [1830]) 'A Summary View of the Principle of Population', in Population Council (ed), On Population: Three Essays, Mentor Books.

Michael Mansell (1992) 'Perspectives on Mabo: The High Court Gives an Inch but Takes Another Mile' 2(57) Aboriginal Law Bulletin 94.

Ernst Mayr (1942) Systematics and the Origin of Species, Columbia University Press.

P McPhee (1999) ' $19^{\text {th }}$ Century Ideologies Live on Today', Courier-Mail, 12 June, Weekend Liftout, p 10.

Neil Brody Miller (2004) "Embalmed in Egyptian Ethnology": Racial Discourse and Antebellum Interest in the Ancient Near East', conference paper delivered to the 2004 ASA Annual Meeting Panel: Science and Race in $19^{\text {th }}$-Century America.

Eleanor Miller and Carrie Yang Costello (2001) 'The Limits of Biological Determinism' 66(4) American Sociological Review 592.

Ashley Montagu (ed) (1980) Sociobiology Examined, Oxford University Press.

Samuel George Morton, 'Observations on Egyptian Ethnology, Derived from Anatomy, History, and the Monuments', in Transactions of the American Philosophical Society IX n. s. (1844).

Julio Munoz-Rubio (2002) 'Sociobiology and Human Nature' 27(2) Interdisciplinary Science Reviews 131.

Julio Munoz-Rubio (2003) 'Charles Darwin: Continuity, Teleology and Ideology' 12(3) Science as Culture 303.

Lyndon Murphy (2000) Who's Afraid of the Dark? Australia's Administration in Aboriginal Affairs, dissertation submitted to the Centre for Public Administration, University of Queensland, in fulfilment of the requirements for the degree of Master of Public Administration.

Robert J Richards (1987) Darwin and the Emergence of Evolutionary Theories of Mind and Behaviour, University of Chicago Press.

Royal Commission Into Aboriginal Deaths in Custody (1991) AGPS, Canberra.

Michael Ruse (2005) The Evolution-Creation Struggle, Harvard University Press.

George H Sabine (1951) A History of Political Theory, 3rd ed, George G Harrap.

Trevor J Saunders (ed) (1992), Aristotle: The Politics, Penguin.

Kay Saunders and Raymond Evans (eds) (1992) Gender Relations in Australia: Domination and Negotiation, Harcourt Brace Jovanovich.

Kim Scott (2001) 'Australia's Continuing Neurosis: Identity, Race and History', The Alfred Deakin Lectures, Melbourne Town Hall, 14 May.

Keith Sealing (2000) 'Blood will Tell: Scientific Racism and the Legal Prohibitions Against Miscegenation' 5 Michigan Journal of Race \& Law 559.

Risto Selin (1999) 'Sociobiology $\neq$ Evolutionary Psychology’ 7(2) Skeptic 22.

Kalpana Seshadri-Crooks (2000) Desiring Whiteness: A Lacanian Analysis of Race, Routledge.

Karl Sigmund and Martin A Nowak (2000) ‘A Tale of Two Selves’ 290 Science 949.

Adam Smith (1970) The Wealth of Nations: Books I-III, ed A Skinner, Penguin.

Herbert Spencer (1857) 'Progress: Its Law and Cause' II Westminster Review 445.

Tony Tinker (1988) 'Panglossian Accounting Theories: The Science of Apologising in Style' 13 Accounting Organizations \& Society 165. 
John van Wyhe (nd) The History of Phrenology on the Web, British Library, http://pages.britishlibrary.net/phrenology/literature.html.

Robert M Young (1985) Darwin's Metaphor, Cambridge University Press.

Alfred Russel Wallace (1864) 'The Origin of Human Races and the Antiquity of Man Deduced from the Theory of "Natural Selection"” 2 Anthropological Review clviii.

John P Watkins (1998) 'Towards a Reconsideration of Social Evolution: Symbiosis and Its Implications for Economics' 32(1) Journal of Economic Issues 87.

John C Weaver (1996) 'Beyond the Fatal Shore: Pastoral Squatting and the Occupation of Australia 1826 to 1852 ' October American Historical Review 981.

Kentwood D Wells (1993) 'An Alternative to Sociobiology' 43(9) Bioscience 646.

Edward O Wilson (1976) Sociobiology: The New Synthesis, Harvard University Press.

Anthony S Wohl (nd), 'Race in Victorian Thought and Science', online paper accessed at The Victorian Web, www.victorianweb.org.

Patrick Wolfe (1999) Settler Colonialism and the Transformation of Anthropology, Cassell.

John van Wyhe (2004 [1847]) George Combe's 'The Constitution of Man in Relation to External Objects' ( $8^{\text {th }}$ ed., 1847), Thoemmes Continuum.

\section{Cases}

Attorney-General v Brown (1847) 1 Legge 312

Buck v Bell 274 US 200 (1927)

Cooper v Stuart (1889) 14 App Cas 286

Mabo v Queensland (1992) 175 CLR 1

Wik Peoples v Queensland (1996) 187 CLR 1 